\title{
Vegetation and macrozoobenthos diversity in the Percut Sei Tuan mangrove forest, North Sumatra, Indonesia
}

\author{
IMAM MAHDI HASIBUAN ${ }^{1}$, RIZKA AMELIA ${ }^{1}$, YUNTHA BIMANTARA ${ }^{1}$, IPANNA ENGGAR SUSETYA ${ }^{2,3}$, \\ ARIDA SUSILOWATI ${ }^{1,3}$, MOHAMMAD BASYUNI ${ }^{1,3, \varphi}$ \\ ${ }^{1}$ Department of Forestry, Faculty of Forestry, Universitas Sumatera Utara. Jl. Tri Darma Ujung No. 1, Medan Baru, Medan 20155, North Sumatra, \\ Indonesia. Tel./fax.: +62-61-8211633, "email: m.basyuni@usu.ac.id \\ ${ }^{2}$ Department of Aquatic Resources Management, Faculty of Agriculture, Universitas Sumatera Utara. J1. Dr. A. Sofian No.3, Medan Baru, Medan 20155, \\ North Sumatra, Indonesia \\ ${ }^{3}$ Center of Excellence for Mangrove, Universitas Sumatera Utara. Jl. Dr. T. Mansur No.9, Medan Baru, Medan 20155, North Sumatra, Indonesia
}

Manuscript received: 21 October 2019. Revision accepted: 27 November 2021.

\begin{abstract}
Hasibuan IM, Amelia R, Bimantara Y, Susetya IE, Susilowati A, Basyuni M. 2021. Vegetation and macrozoobenthos diversity in the Percut Sei Tuan mangrove forest, North Sumatra, Indonesia. Biodiversitas 22: 5600-5608. The mangrove forest offers a habitat for a variety of marine species, including macrozoobenthos. Macrozoobenthos live at the bottom of the waters on hard to muddy substrates, where they break down mangrove debris, ensuring microorganisms' ease in decomposing organic matter into inorganic materials that provide nutrients to producers in the water. The study aimed to determine the vegetation and macrozoobenthos diversity in the Percut Sei Tuan mangrove forest, North Sumatra, Indonesia. This research was executed with vegetation analysis, employing a sampling method in the form of plots, as many as three transects and 66 plots. The sampling of macrozoobenthos was conducted on the substrate surface, roots, and mangrove trunk for three stations and nine plots with a size of $1 \mathrm{~m} \mathrm{x} 1 \mathrm{~m}$. We found 10 true mangrove species where Avicennia marina was the most abundant, found at each seedling, sapling, and tree-stage with an important value index (IVI) of $64.62 \%, 75.73 \%$, and $92.12 \%$, respectively. Overall, the number of individuals in the species found was $1666.67 / \mathrm{Ha}$ at the seedling stage, 1090.91/ $\mathrm{Ha}$ at the sapling stage, and $842.42 / \mathrm{Ha}$ at the tree stage. Seven macrozoobenthos species were found and classified into four classes of Gastropoda, Polychaeta, Mollusca, and Arthropoda, with population abundance values being 9.33 ind $/ \mathrm{m}^{2}$ at a station I, $7.44 \mathrm{ind} / \mathrm{m}^{2}$ at station II, and $8.78 \mathrm{ind} / \mathrm{m}^{2}$ at station III. The diversity index $\left(\mathrm{H}^{\prime}\right)$ of the observed location was determined to be 1.63-2.06, which was classified into the medium category, while $\mathrm{H}^{\prime}$ macrozoobenthos ranging from 1.54-1.81 were classified into the low to moderate category. The observed parameters' physical and chemical factors presented that the condition of the waters in the research area is still considered suitable for supporting macrozoobenthos life, with dissolved oxygen being strongly correlated to macrozoobenthos diversity.
\end{abstract}

Keywords: Biodiversity, community assemblage, macrozoobenthic, natural mangrove, physicochemical characteristic

\section{INTRODUCTION}

Mangrove forests are located in coastal areas and salt marshes which are affected by tides and can also grow in tropical and subtropical coastal areas (Balke et al. 2013, 2015; Bryan-Brown et al. 2020). Ecologically, mangroves play a role in producing oxygen and absorbing carbon dioxide, climate change mitigation efforts, as a water nutrition provider, and as a habitat for various types of animals even though the area comprises merely of $0.5 \%$ of the world's coastal areas (Alongi 2014; Murdiyarso et al. 2015).

Macrozoobenthos are a group of aquatic organisms that have a crucial part in aquatic ecosystems; it can live on hard to muddy substrates by making holes, crawling, sticking, burying, digging both at the bottom and surface of the waters, and live by sticking to mangrove trees (Tapilatu and Pelasula 2012; Basyuni et al. 2018; Chen et al. 2018). It is often used as a bioindicator to assess the status of water quality due to its relatively low movement; a change in water quality will have a significant impact on macrozoobenthos (Bayan et al. 2016; Susetya et al. 2018).
Based on its role and functions, macrozoobenthos may decompose mangrove waste, facilitating the process for microorganisms to convert organic matter into inorganic materials and provide nutrients to producers in the waters (Muhammad et al. 2017). Macrozoobenthos found in mangrove forest areas come from Class Mollusca, Polychaeta, Bivalvia, Arthropoda, and Malacostraca (Basyuni et al. 2018). Several factors affect the population of macrozoobenthos: physicochemical properties in the aquatic environment, the entry of oxygenated water changing water quality and heavy metal content in sediments and water depths, as well as biotic factors such as mangrove plants being a source of food jointly affects the community structure and distribution of macrozoobenthos (Obolewski 2011; Li et al. 2020).

The current mangrove ecosystem continues to be damaged due to changes in land use and land cover without regard to environmental aspects, as in the mangrove forests of North Sumatra, Percut Sei Tuan district (Bryan et al. 2013; Sasmito et al. 2019; Basyuni et al. 2021). Percut Sei Tuan is a coastal area located on the East Coast of North Sumatra. As a coastal area includes rivers with several 
tributaries, the reduced area of mangroves and their damage can also affect the abundance of fauna-especially the macrozoobenthos in the area (Susetya et al. 2021). The aim of the present study was to determine the diversity of vegetation and macrozoobenthos in the mangroves of Percut Sei Tuan, North Sumatra, Indonesia.

\section{MATERIALS AND METHODS}

\section{Study area}

The research for this study was conducted from February to March 2021 in the mangrove forest of Tanjung Rejo Village, Percut Sei Tuan district, Deli Serdang Regency, North Sumatra, Indonesia. The sampling locations were divided into three different stations: Station I is located at $3^{\circ} 44^{\prime} 03.09^{\prime \prime}-3^{\circ} 44^{\prime} 06.23^{\prime \prime}$ North Latitude and between $98^{\circ} 46^{\prime} 22.14^{\prime \prime}-98^{\circ} 46^{\prime} 19.72^{\prime \prime}$ East Longitude, Station II at N $3^{\circ} 44^{\prime} 04.02^{\prime \prime}-3^{\circ} 44^{\prime} 06.98^{\prime \prime}$ and between E $98^{\circ} 46^{\prime} 22.94^{\prime \prime}-98^{\circ} 46^{\prime} 20.49^{\prime \prime}$, and Station III at N $3^{\circ} 44^{\prime} 06.57^{\prime \prime}-3^{\circ} 44^{\prime} 09.23^{\prime \prime}$ and between E 98 $46^{\prime} 24.26^{\prime \prime}$ $98^{\circ} 46^{\prime 2} 21.81^{\prime \prime}$ (Figure 1). The mangrove ecosystem on the coast of the Tanjung Rejo village contains vegetation that is either distributed naturally or planted by the local community.

\section{Vegetation analysis}

The vegetation analysis executed at the mangrove forest had three sampling stations, within which three plots (triplicates) were determined to collect basic forest stand attributes. The data collection technique, performed following Pearson et al. (2005), gathered information from three transects of $100 \mathrm{~m}$ inland perpendicular to the coastline, on transect I, there was as many as 25 plots, transect 2 had 23 plots, and transect 3 had 18 plots (Figure 1). Each plot measured $10 \mathrm{~m} \times 10 \mathrm{~m}$ for trees, $5 \mathrm{~m} \mathrm{x} 5 \mathrm{~m}$ for saplings, and $2 \mathrm{~m} \times 2 \mathrm{~m}$ for seedlings. The identification of the species was carried out using a mangrove identification book which is referred to in both Kitamura et al. (2003) and Noor et al. (2006).

\section{Frequency (F), Density (A), and Dominance (D)}

Species frequency is a value that provides the distribution of the species in the plot.

$$
\begin{aligned}
& \text { Frequency }(\mathrm{F})=\frac{\text { the number of plots there are types }}{\text { sum of all plots }} \\
& \text { Relative Frequency }(\mathrm{RF})=\frac{\text { Frequency of a type } x 10036}{\text { All kinds of frequency }}
\end{aligned}
$$

Abundance is a way of determining the number of individuals in a plot. The density value is calculated by the formula:

$$
\text { Density }(A)=\frac{\begin{array}{l}
\text { Number of individuals of a species } \\
\text { Sample plot area }
\end{array}}{\text { Density of a species } \quad \times 10036}
$$

Dominance specifies the dominance of the species contained in the plot, the value of which is obtained by calculating the base area of a species and dividing it by the area of the entire plot.

$$
\begin{aligned}
& \text { BA }=\frac{\text { basal area of species }}{\text { Sample plot area }} \\
& \text { RBA }=\frac{\text { Dominance of species x } 10036}{\text { Dominance of all species }}
\end{aligned}
$$

Where, BA: Basal area; RBA: Relative basal area.
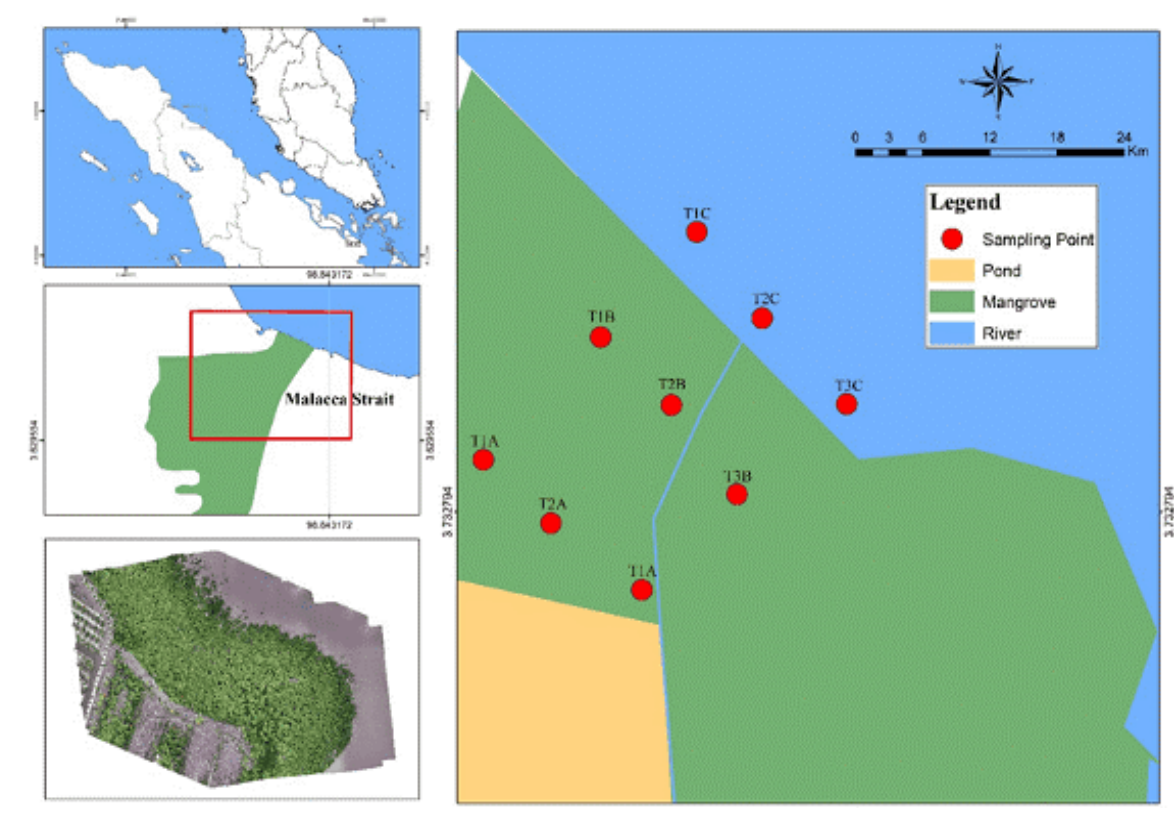

Figure 1. Map of sites in Percut Sei Tuan, North Sumatra Province, Indonesia 
Important Value Index (IVI)

The important value index is the mastery value of each type of vegetation in an area. Significant values are calculated with the following formula:

$\mathrm{IVI}=\mathrm{RF}+\mathrm{RA}$ (for seedlings and saplings)

$\mathrm{IVI}=\mathrm{RF}+\mathrm{RA}+\mathrm{RBA}$ (for trees)

\section{Diversity Index}

Diversity $\left(\mathrm{H}^{\prime}\right)$ is a parameter of vegetation that can adapt to various plant communities. In a community, there are several types of plants, therefore, the more stable the community, the higher the diversity of plant species. Species diversity can be calculated using the Shannon Index formula (Barbour et al. 1987).

$$
\mathrm{H}^{\prime}=-\sum\{(\mathrm{ni} / \mathrm{N}) \ln (\mathrm{ni} / \mathrm{N})\}
$$

Information: H': Shannon Wiener's diversity index; Ni: Number of individuals of a species; N: Total number of individuals of a species.

Where, H' 0-2: Low/little species diversity; H'2-3: Medium species diversity; H' > 3: High species diversity.

The higher the value of diversity, the better the ecosystem. Conversely, it can be said that the ecosystem is extremely susceptible to pests and diseases the smaller this value is. The diversity index can also be calculated using the taxonomy index (Clarke and Warwick 2001).

$$
\Delta^{+}=\left[\sum \sum \mathrm{i}<\mathrm{j} \omega \mathrm{ij}\right] /[\mathrm{S}(\mathrm{s}-1) / 2]
$$

Where, $\Delta+$ : Taxonomy index; S: Number of species present and for double addition; $\mathrm{i}$ and $\mathrm{j}$ : Range of species presence.

The taxonomic diversity index is used to identify similarities or comparisons with the Shannon-Wiener index.

\section{Macrozoobenthos analysis}

For determining the station, a $1 \mathrm{~m} \times 1 \mathrm{~m}$ plot with a $1 \mathrm{~m}$ x $1 \mathrm{~m}$ horizontally arranged paralon pipe has been utilized. Sampling was carried out at three stations, each with three plots and each plot repeated three times. Macrozoobenthos samples can be discovered directly on the surface of the substrate, roots, and mangrove stems while looking for worms by dredging the substrate and then filtering it with a $1 \mathrm{~mm}$ filter eye. The water is filtered to facilitate its separation from the substrate. Furthermore, samples of macrozoobenthos were put into bottle plastics and immersed in $70 \%$ alcohol for preservation. The samples were identified, and the validity of the scientific names was further verified through the World Register of Marine Species database (http://www.marinespecies.org), and the revised names were updated.

\section{Data analysis of macrozoobenthos}

Abundance (A) and Relative Abundance (RA)

The abundance of individual macrozoobenthos is defined as the number of species at the station in cubic units, with the formula:

$$
\begin{aligned}
& \mathrm{A}=\frac{\frac{\text { Number of species }(\mathrm{ind})}{\text { Sample plot area }\left(\mathrm{m}^{2}\right)}}{\mathrm{RA}=\text { ni } \times 100 \% \mathrm{~N}}
\end{aligned}
$$

Information: RA: Relative abundance; Ni: Number of individuals of type I; N: Total number of individuals.

\section{Diversity Index $\left(H^{\prime}\right)$, Uniformity Index $(E)$, and Dominance Index $(D)$}

The diversity index $\left(\mathrm{H}^{\prime}\right)$ provides a mathematical description of the population of organisms. The diversity of macrozoobenthos species can be calculated using the Shannon-Wiener diversity index (Odum 1993).

$$
\mathrm{H}^{\prime}=-\sum\{(\mathrm{ni} / \mathrm{N}) \ln (\mathrm{ni} / \mathrm{N})\}
$$

Information: H': Shannon Wiener's diversity index; Ni: Number of individuals of a species; $\mathrm{N}$ : Total number of individuals of a species.

Where, H' 0-2: Low/little species diversity; H' 2-3: Medium species diversity; $\mathrm{H}^{\prime}>3$ : High species diversity.

According to Shannon Wiener, the higher the value of diversity, the better the ecosystem. Conversely, if the diversity value is small, the ecosystem will be highly vulnerable to pests and diseases.

Uniformity is the composition of the number of individuals of each genus in the community. The uniformity index used is based on the Shannon-Wiener function to obtain the distribution of the macrozoobenthos species within the observed area (Odum 1993).

$$
\mathrm{E}=\frac{H^{s}}{H^{v} \operatorname{mahs}}=\frac{H^{s}}{\operatorname{In}\left(\ln _{s}\right)}
$$

Information: E: Uniformity index; $S$ : Number of species; H': Shannon-Wiener diversity index; ln: Natural logarithm; H max: Maximum species diversity.

The value of uniformity in the population ranges from 0-1 with the following criteria (Odum 1993): E > 0.6: High uniformity; $0.4<\mathrm{E}<0.6$ : Medium uniformity; $\mathrm{E}<0.4$ : Low uniformity.

The dominance index is used to obtain information about the dominant family in a community, the calculation of which is conducted with the Simpson formula as follows (Odum 1993):

$$
\mathrm{D}=\sum(\mathrm{Pi})^{2}
$$

Information: Pi: ni/N; D: Dominance index; ni: Number of individuals I; N: Total number of individuals.

Criteria (Odum 1993), D value close to 0: No type dominates; D value close to 1: There is a dominant type.

\section{Measurement of physical and chemical parameters}

The physical and chemical parameters were measured in situ at the observation site, and the measurement plot was determined by sampling macrozoobenthos. The temperature is measured using a portable thermometer. Dissolved oxygen (DO) was measured using a DO meter 
(Lutron DO-5510), and $\mathrm{pH}$ was gauged using a $\mathrm{pH}$ meter (EcoTestr pH 2, Eutech). Salinity was computed using a refractometer (Atago Master S28 M), and for the chemical analysis of soil, N-Total, P-Total, and K-Total were analyzed in the PT. Socfindo laboratory.

The correlation between the macrozoobenthos diversity index $\left(\mathrm{H}^{\prime}\right)$ and environmental parameters was examined using the Pearson correlation by the SPSS 21.0 software to verify the correlation value of macrozoobenthos and environmental conditions as the limiting factor (Samidurai et al. 2012). Before analyzing the correlation test as a parametric test, the data normality was tested to run normally distributed. The significance value of the variable is $\mathrm{P}<0.05$ indicates that there is a significant relationship between the two variables. If $\mathrm{P}>0.05$, there would be no significant relationship between the two variables.

\section{RESULTS AND DISCUSSION}

\section{Vegetation analysis}

At the research site, 10 true mangrove species were found, out of which seven were discovered at the seedling stage, 10 at the sapling stage, and six species at the tree stage (Table 1). Based on the research by Ningsih et al. (2011), additional species were also present, namely eight species. Avicennia marina was found to be the most common species in each growth stage, whereas Bruguiera gymnorrhiza, Ceriops tagal, Lumnitzera racemosa, and Scyphiphora hydrophyllacea were absent in the tree stage (Table 1). This study was conducted in an area bordering the sea that was overgrown by the species of $A$. alba, $A$. marina, A. officinalis, Rhizophora apiculata, and $R$. stylosa. This is in line with Afefe et al. (2019) study, which stated that ideal mangroves growing close to the sea are commonly covered by the Avicennia spp. and associated with Rhizophora spp in sandy or mixed soil types.

The number of individual $A$. marina was $548.48 /$ ha at the seedling level, 375.76/ha for saplings, and 331.82/ha for trees. A. marina is a species that lives in wetlands and waterlogged areas. Since the area of research is close to the sea and possesses high salinity, A. marina dominates the numbers, followed by $R$. apiculata. A. marina has certain habitat characteristics such as high $\mathrm{pH}$, temperature, thick mud, and the ability to tolerate a very low salinity range of up to $90 \%$ (Poedjirahajoe et al. 2017; Balke et al. 2021). As it has breathing roots, this species can survive in places that are usually submerged in water at high tide. Overall, the number of individuals found at the study site at the tree level came up to $842.42 / \mathrm{Ha}$. Based on the Decree of the Minister of the Environment No. 201 of 2004 (KepMen LH No. 201 the year 2004), the standard criteria and guidelines for mangrove damage are classified as rare, or the criteria for damage is $<50 \%$.

Table 1. Plant composition at an individual level

\begin{tabular}{llccc}
\hline \multicolumn{1}{c}{ Species } & \multicolumn{2}{c}{ Family } & \multicolumn{2}{c}{ Individual-level/Ha } \\
\cline { 3 - 5 } & & Seedling & Sapling & Tree \\
\hline Avicennia alba & Acanthaceae & 183.33 & 65.15 & 75.76 \\
Avicennia marina & Acanthaceae & 548.48 & 375.76 & 331.82 \\
Avicennia officinalis & Acanthaceae & 157.58 & 86.36 & 119.70 \\
Bruguiera gymnorrhiza & Rhizophoraceae & 216.67 & 100.00 & 0 \\
Ceriops tagal & Rhizophoraceae & 189.39 & 80.30 & 0 \\
Excoecaria agallocha & Euphorbiaceae & 0 & 57.58 & 96.97 \\
Lumnitzera racemosa & Combretaceae & 0 & 74.24 & 0 \\
Rhizophora apiculata & Rhizophoraceae & 221.21 & 136.36 & 136.36 \\
Rhizophora stylosa & Rhizophoraceae & 150.00 & 54.55 & 81.82 \\
Scyphiphora hydrophyllacea & Rubiaceae & 0 & 60.61 & 0 \\
Total & & $\mathbf{1 6 6 6 . 6 7}$ & $\mathbf{1 0 9 0 . 9 1}$ & $\mathbf{8 4 2 . 4 2}$ \\
\hline
\end{tabular}

Table 2. Mean height and diameter at the seedling, sapling, and tree stages

\begin{tabular}{|c|c|c|c|c|c|}
\hline \multirow{2}{*}{ Species } & \multicolumn{3}{|c|}{ Mean height } & \multicolumn{2}{|c|}{ Mean diameter } \\
\hline & Seedling (cm) & Sapling (M) & Tree $(\mathbf{M})$ & Sapling (cm) & Tree $(\mathbf{c m})$ \\
\hline Avicennia alba & $51.20 \pm 22.51$ & $3.68 \pm 1.34$ & $8.12 \pm 4.16$ & $3.50 \pm 0.92$ & $16.26 \pm 4.39$ \\
\hline Avicennia marina & $51.89 \pm 22.95$ & $3.71 \pm 1.34$ & $6.65 \pm 3.76$ & $3.58 \pm 1.27$ & $15.69 \pm 4.94$ \\
\hline Avicennia officinalis & $51.26 \pm 24.04$ & $3.77 \pm 1.55$ & $5.68 \pm 3.06$ & $3.33 \pm 1.23$ & $16.26 \pm 4.66$ \\
\hline Bruguiera gymnorrhiza & $60.27 \pm 21.88$ & $3.67 \pm 1.50$ & - & $3.27 \pm 1.11$ & - \\
\hline Ceriops tagal & $53.34 \pm 24.38$ & $4.06 \pm 1.65$ & - & $3.81 \pm 1.46$ & - \\
\hline Excoecaria agallocha & - & $3.52 \pm 1.29$ & $5.80 \pm 2.78$ & $3.24 \pm 1.23$ & $14.43 \pm 3.44$ \\
\hline Lumnitzera racemosa & - & $4.00 \pm 1.80$ & - & $3.33 \pm 1.00$ & - \\
\hline Rhizophora apiculata & $55.01 \pm 24.38$ & $3.78 \pm 1.42$ & $7.99 \pm 4.37$ & $3.65 \pm 1.03$ & $16.31 \pm 6.19$ \\
\hline Rhizophora stylosa & $52.89 \pm 27.75$ & $3.39 \pm 0.99$ & $7.80 \pm 4.50$ & $3.45 \pm 0.92$ & $17.16 \pm 7.65$ \\
\hline Scyphiphora hydrophyllacea & - & $3.94 \pm 1.73$ & - & $3.44 \pm 1.24$ & - \\
\hline
\end{tabular}

Note: (-) none 
Table 3. Density, frequency, dominance at the seedling, sapling, and tree stages

\begin{tabular}{|c|c|c|c|c|c|c|c|c|}
\hline \multirow{2}{*}{ Species } & \multicolumn{3}{|c|}{ Density (Individual/ha) } & \multicolumn{2}{|c|}{ Frequency (\%) } & \multicolumn{3}{|c|}{ Dominance $\left(\mathrm{m}^{2} / \mathrm{ha}\right)$} \\
\hline & Seedling & Sapling & Tree & Seedling & Sapling & Tree & Sapling & Tree \\
\hline Avicennia alba & 0.46 & 0.03 & 0.01 & 0.32 & 0.14 & 0.21 & 0.01 & 0.03 \\
\hline Avicennia marina & 1.37 & 0.15 & 0.03 & 0.98 & 1.00 & 0.86 & 0.01 & 0.03 \\
\hline Avicennia officinalis & 0.39 & 0.03 & 0.01 & 0.33 & 0.29 & 0.35 & 0.01 & 0.03 \\
\hline Bruguiera gymnorrhiza & 0.54 & 0.04 & - & 0.45 & 0.33 & - & 0.01 & - \\
\hline Ceriops tagal & 0.47 & 0.03 & - & 0.38 & 0.26 & - & 0.01 & - \\
\hline Excoecaria agallocha & - & 0.02 & 0.01 & - & 0.18 & 0.30 & 0.01 & 0.02 \\
\hline Lumnitzera racemosa & - & 0.03 & - & - & 0.24 & - & 0.01 & - \\
\hline Rhizophora apiculata & 0.55 & 0.05 & 0.01 & 0.38 & 0.39 & 0.36 & 0.01 & 0.03 \\
\hline Rhizophora stylosa & 0.38 & 0.02 & 0.01 & 0.26 & 0.21 & 0.26 & 0.01 & 0.04 \\
\hline Scyphiphora hydrophyllacea & - & 0.02 & - & - & 0.23 & - & 0.01 & - \\
\hline Total & 4.17 & 0.44 & 0.08 & 3.11 & 3.27 & 2.35 & 0.06 & 0.18 \\
\hline
\end{tabular}

Note: (-) none

The species diversity index is a value that presents the diversity of the species found at the research site (Baderan et al. 2019). Specific abundance is a value proving the number of individuals of a species per unit area. The greater the density of a species, the more individual species per unit area. The highest species density was found in $A$. marina seedlings with a value of $1.37 \mathrm{idv} / \mathrm{m}^{2}$; this was due to the suitable habitat and strength of the species in adapting to its environment. Environmental conditions with sandy mud substrate can encourage the development of the A. marina species (Noor et al. 2006).

The highest species frequency was found in the growth rate of A. marina species with a value of 1.00. Species frequency describes the chance or chances of finding the species in the location area, i.e., the observation area. The $R$. stylosa species has a dominance value of 0.04 . According to Ghufrona et al. (2015), the species dominance index is the control of a species in a location. The most important species define the control value of species in a community. The significance of a species can be used as an indicator that it is considered dominant by having a higher $\mathrm{RD}, \mathrm{RF}$, and RD value than other species (Sreelekshmi et al. 2020).

RD describes the density of the species in comparison to the whole species in an area. The species with the highest RD was A. marina at the tree level at $39.39 \%$. This is in accordance with Parmadi et al. (2016), who declared that the high RD of A. marina is influenced by a substrate with a muddy type of sand. The highest RF value was found in the growth rate of A. marina trees with a value of $31.71 \%$ and the lowest at the sapling growth rate of $A$. alba with a value of $4.17 \%$.

Dominance is the comparison between the base area and area of the plot, while RD is the overall dominance of a species. The highest RD was identified in $R$. stylosa (19.07\%), while the lowest was in E. agallocha (8.77\%). This is attributed to the fact that $R$. stylosa has a suitable substrate for the research location, namely sandy mud. According to Hidayatullah and Eko (2014), dominance is influenced by the same soil texture at the study site, and zoning is also included in the factors influencing the dominance of a species.

The important value index (IVI) is crucial in determining the occurrence of a species in a community. $A$. marina was the species with the top rank based on IVI on the seedling, sapling, and tree stages (Table 5). The IVI demonstrates a species' level of dominance, and A. marina is the most important mangrove species in the study area. Species with the greatest IVI possess better adaptability and reproductive ability compared to other species in similar habitats. The highest IVI indicates that the species can be regenerated by adapting well to the mangrove environment (Simamora et al. 2014).

Table 4. Relative density (RD), relative frequency (RF), and relative basal area (RBA) at the seedling, sapling, and tree stages

\begin{tabular}{lcccccccc}
\hline \multirow{2}{*}{ Species } & \multicolumn{3}{c}{ RD } & \multicolumn{3}{c}{ RF } & \multicolumn{2}{c}{ RBA } \\
\cline { 2 - 8 } & Seedling (\%) & Sapling (\%) & Tree (\%) & Seedling (\%) & Sapling (\%) & Tree (\%) & Sapling (\%) & Tree (\%) \\
\hline Avicennia alba & 11.00 & 5.98 & 8.99 & 10.24 & 4.17 & 9.03 & 10.18 & 17.12 \\
Avicennia marina & 32.91 & 34.47 & 39.39 & 31.71 & 30.56 & 36.77 & 10.70 & 15.95 \\
Avicennia officinalis & 9.45 & 7.92 & 14.21 & 10.73 & 8.80 & 14.84 & 9.22 & 17.12 \\
Bruguiera gymnorrhiza & 13.00 & 9.17 & - & 14.63 & 10.19 & - & 8.91 & - \\
Ceriops tagal & 11.36 & 7.37 & - & 12.20 & 7.87 & - & 12.11 & - \\
Excoecaria agallocha & - & 5.28 & 11.51 & - & 5.56 & 12.90 & 8.77 & 13.49 \\
Lumnitzera racemosa & - & 6.81 & - & - & 7.41 & - & 9.23 & - \\
Rhizophora apiculata & 13.27 & 12.51 & 16.19 & 12.20 & 12.04 & 15.48 & 11.10 & 17.24 \\
Rhizophora stylosa & 9.00 & 5.00 & 9.71 & 8.29 & 6.48 & 10.97 & 9.93 & 19.07 \\
Scyphiphora hydrophyllacea & - & 5.56 & - & - & 6.94 & - & 9.85 & - \\
\hline
\end{tabular}


Table 5. Important value index at seedling, sapling, and tree stages

\begin{tabular}{|c|c|c|c|}
\hline \multirow[b]{2}{*}{ Species } & \multicolumn{3}{|c|}{ Important value index (IVI) } \\
\hline & $\begin{array}{c}\text { Seedling } \\
(\%)\end{array}$ & $\begin{array}{c}\text { Sapling } \\
(\%)\end{array}$ & $\begin{array}{l}\text { Tree } \\
(\%)\end{array}$ \\
\hline Avicennia alba & 21.24 & 20.32 & 35.15 \\
\hline Avicennia marina & 64.62 & 75.73 & 92.12 \\
\hline Avicennia officinalis & 20.19 & 25.94 & 46.17 \\
\hline Bruguiera gymnorrhiza & 27.63 & 28.27 & - \\
\hline Ceriops tagal & 23.56 & 27.35 & - \\
\hline Excoecaria agallocha & - & 19.61 & 37.90 \\
\hline Lumnitzera racemosa & - & 23.45 & - \\
\hline Rhizophora apiculata & 25.47 & 35.65 & 48.91 \\
\hline Rhizophora stylosa & 17.29 & 21.42 & 39.75 \\
\hline Scyphiphora hydrophyllacea & - & 22.35 & - \\
\hline
\end{tabular}

note: (-) not detected

The highest diversity index at the seedling stage was also found in A. marina with a value of 0.37 (Table 6). While the lowest was $R$. stylosa and A. officinalis, both with the value of 0.22 . At the sapling stage, the highest diversity index was found in the A. marina species with a value of 0.37 while the lowest was in $R$. stylosa at 0.15 . At the tree stage, the highest was again $A$. marina with a value of 0.37 while the lowest was $A$. alba with 0.22 . Low diversity implies that the ecosystem is under pressure (Singh 2020) and in declining conditions (Macusi et al. 2021). As the mangroves live in environments with high salinity and muddy substrates, survival only occurs for those species with high adaptation abilities after a strict selection (Noor et al. 2006).

The level of mangrove diversity in Percut Sei Tuan is classified into low criteria in seedlings and trees, while saplings are classified into the moderate criteria (Barbour et al. 1987). The low diversity of mangrove species in the study area might be attributed to environmental conditions that are only able to support the growth of certain species or because the mangrove species utilize their greater regeneration power.

The highest taxonomic diversity index for the seedling stages was confirmed to be in the A. marina species with a value of 0.16 and the lowest was in $R$. stylosa (Table 7). At the sapling stage, A. marina still owned the highest value at 0.17 and the lowest with a value of 0.02 was found in $R$. stylosa. At the tree stage, once again, A. marina dominated with a value of 0.20 , while $R$. apiculata and $A$. alba had the lowest value of 0.04 . The diversity index in a community greatly influences the number of individuals and species in the community. Eddy et al. (2021) claimed that species diversity in a community would be high if the community consisted of several species and no species was dominant. Conversely, if a community has a low diversity value, then it will consist of species and additionally, there will be a dominant species.

\section{Identification of macrozoobenthos}

Four classes of the macrozoobenthos were found in the Percut Sei Tuan mangrove forest in North Sumatra: Mollusca, Gastropod, Arthropod, and Polychaete. This finding is rather similar with previous research conducted by Basyuni et al. (2018), who found three classes of macrozoobenthos, namely Gastropoda, Bivalves, and Malacostraca. The species most commonly found are from the class Gastropoda with $9.44 / \mathrm{m}^{2}$ (Table 8 ). It has a high tolerance to environmental changes, as well as high adaptability and a wide distribution range. Polychaeta, consisting of solely one species, might be caused by its slow response-ability. This is in accordance with Kasumyan (2019), who stated that in certain soft-bodied animals, such as Polychaeta worms, osmotic regulation mechanisms were developed, but the response was relatively slow.

\section{Individual-level and ecological index of macrozoobenthos at each research station}

Based on the observation of the number of macrozoobenthos obtained at each station, the abundance value of the population at a station $\mathrm{I}$ is $9.33 \mathrm{ind} / \mathrm{m}^{2}$, with $7.44 \mathrm{ind} / \mathrm{m}^{2}$ at station II and $8.78 \mathrm{ind} / \mathrm{m}^{2}$ at station III (Table 9). This value indicates that station I own the highest population abundance value while station III has the lowest. The high abundance of macrozoobenthos at a station I is caused by natural environmental conditions, including the condition of mangroves that can meet the life of macrozoobenthos. The abundance of macrozoobenthos is influenced by biotic and abiotic factors in the mangrove ecosystem. According to Basyuni et al. (2018), its high abundance is attributed to environmental conditions that allow macrozoobenthos to survive.

Table 6. Shannon Wiener diversity index at seedling, sapling, and tree levels

\begin{tabular}{lccc}
\hline \multirow{2}{*}{ Species } & \multicolumn{3}{c}{ Diversity index (H') } \\
\cline { 2 - 4 } & Seedling & Sapling & Tree \\
\hline Avicennia alba & 0.24 & 0.17 & 0.22 \\
Avicennia marina & 0.37 & 0.37 & 0.37 \\
Avicennia officinalis & 0.22 & 0.20 & 0.28 \\
Bruguiera gymnorrhiza & 0.27 & 0.22 & - \\
Ceriops tagal & 0.25 & 0.19 & - \\
Excoecaria agallocha & - & 0.16 & 0.25 \\
Lumnitzera racemosa & - & 0.18 & - \\
Rhizophora apiculata & 0.27 & 0.26 & 0.29 \\
Rhizophora stylosa & 0.22 & 0.15 & 0.23 \\
Scyphiphora hydrophyllacea & - & 0.16 & - \\
Total & $\mathbf{1 . 8 3}$ & $\mathbf{2 . 0 6}$ & $\mathbf{1 . 6 3}$ \\
\hline No:
\end{tabular}

Note: (-) none

Table 7. Taxonomic index at seedling, sapling, and tree levels

\begin{tabular}{lccc}
\hline \multirow{2}{*}{ Species } & \multicolumn{3}{c}{ Taxonomic diversity index } \\
\cline { 2 - 4 } & Seedling & Sapling & Tree \\
\hline Avicennia alba & 0.05 & 0.03 & 0.04 \\
Avicennia marina & 0.16 & 0.17 & 0.20 \\
Avicennia officinalis & 0.05 & 0.04 & 0.07 \\
Bruguiera gymnorrhiza & 0.06 & 0.05 & - \\
Ceriops tagal & 0.06 & 0.04 & - \\
Excoecaria agallocha & - & 0.03 & 0.06 \\
Lumnitzera racemosa & - & 0.03 & - \\
Rhizophora apiculata & 0.07 & 0.06 & 0.08 \\
Rhizophora stylosa & 0.04 & 0.02 & 0.05 \\
Scyphiphora hydrophyllacea & - & 0.03 & - \\
Total & $\mathbf{0 . 5 0}$ & $\mathbf{0 . 4 9}$ & $\mathbf{0 . 4 9}$ \\
\hline Note: (-) nond
\end{tabular}

Note: (-) none 
Table 8. Identification of macrozoobenthos

\begin{tabular}{|c|c|c|c|c|c|c|}
\hline \multirow{2}{*}{ Class } & \multirow{2}{*}{ Family } & \multirow{2}{*}{ Species } & \multicolumn{3}{|c|}{ Station } & \multirow{2}{*}{$\begin{array}{c}\text { Individual-level } \\
\text { ind } / \mathrm{m}^{2}\end{array}$} \\
\hline & & & 1 & 2 & 3 & \\
\hline Mollusc & Ellobiidae & Cassidula angulifera & + & + & + & 4.22 \\
\hline Mollusc & Ellobiidae & Cassidula nucleus & + & + & + & 1.67 \\
\hline Gastropod & Potamididae & Cerithidea obtusa & + & + & + & 8.33 \\
\hline Gastropod & Ellobiidae & Ellobium aurisjudae & + & + & + & 1.11 \\
\hline Arthropod & Sesarmidae & Episesarma versicolor & + & + & + & 7.44 \\
\hline Polychaete & Nereididae & Nereis sp & + & + & + & $1 ., 67$ \\
\hline Arthropod & Ocypodidae & Uca tetragonon & + & - & - & 1.11 \\
\hline Total & & & & & & 25.56 \\
\hline
\end{tabular}

Note: (-) none

Table 9. Individual-level and ecological index of macrozoobenthos at each research station

\begin{tabular}{ccccc}
\hline $\begin{array}{c}\text { Station/ } \\
\text { transect }\end{array}$ & $\begin{array}{c}\text { Individual-level } \\
\text { ind } / \mathbf{m}^{\mathbf{2}}\end{array}$ & Diversity index (H) & Eniformity index (E) & Dominance index (D) \\
\cline { 3 - 5 } & 9.33 & 1.81 & 0.93 & 0.19 \\
2 & 7.44 & 1.27 & 0.71 & 0.34 \\
3 & 8.78 & 1.54 & 0.86 & 0.25 \\
\hline
\end{tabular}

The diversity index value of macrozoobenthos ranges from 1.54 to 1.81 , which is classified into the low to a medium category, while the uniformity index value ranges from 0.71 to 0.93 and is included in the high category (Table 9). The dominance index value ranges from 0.19 to 0.34 and belongs in the non-dominant category. The indexes of diversity, uniformity, and dominance are widely used in evaluating the aquatic environment based on its biological conditions. The unbalanced environmental conditions will affect organisms living in the waters (Odum 1993). The diversity index value has the highest value at the station I at 1.81 and is grouped into the moderate category. Theuerkauff et al. (2018) reported that species diversity is the variation in an ecosystem; when it has a high diversity index, the ecosystem tends to be balanced and vice versa.

The uniformity index displayed the highest value at the station I at 0.93 and fell under the high category. According to Gravina et al. (2020), the uniformity index determines if there exists a dominant pattern of one or many species groups in the observed environment. If the uniformity index value is equal to one, the distribution of individuals among species is quite even. If it is close to 0 , there are certain groups of species that are relatively more abundant than other species. The dominance index in station II also exhibits a high value (0.34), so it can also be classified as a dominant species. This is in accordance with Odum (1993), who expressed that the dominance index value varies from
0 to 1 ; if the dominance index value is close to 0 , no individual species dominates; conversely, if the dominance index value is close to 1 , there is a dominant individual. A high dominance index value indicates a high concentration of dominance, and a low value, on the other hand, indicates a low concentration.

\section{Relationship between macrozoobenthos diversity and environmental parameters}

The Pearson correlation with SPSS 21.0 software has been employed in examining the relationship between the value of the Macrozoobenthos Diversity Index $\left(\mathrm{H}^{\prime}\right)$ and environment conditions (Table 10). The presence of macrozoobenthos in mangrove waters is strongly influenced by various environmental factors: temperature, pH, salinity, and DO (Harahap et al. 2018).

Table 10. Relationship of macrozoobenthos diversity and environmental parameters using Pearson correlation

\begin{tabular}{lccc}
\hline \multicolumn{1}{c}{ Parameter } & $\begin{array}{c}\boldsymbol{P} \\
\text { value }\end{array}$ & $\begin{array}{c}\text { Pearson } \\
\text { correlation }\end{array}$ & $\begin{array}{c}\text { Correlation } \\
\text { type }\end{array}$ \\
\hline Salinity $(\%)$ & 0.31 & 0.38 & Low \\
pH & 0.37 & 0.34 & Low \\
Dissolved oxygen $(\mathrm{DO})(\mathrm{mg} / \mathrm{l})$ & 0.045 & 0.68 & High \\
Temperature $\left({ }^{\circ} \mathrm{C}\right)$ & 0.39 & 0.33 & Low \\
\hline
\end{tabular}

Table 11. Physical and chemical habitat characteristics of mangroves at each station

\begin{tabular}{ccccc}
\hline \multirow{2}{*}{ Station } & \multicolumn{4}{c}{ Physical and chemical habitat characteristics of mangroves } \\
\cline { 2 - 5 } & Salinity (\%) & $\mathbf{p H}$ & Dissolved oxygen $(\mathbf{m g} / \mathbf{l})$ & Temperature $\left({ }^{\circ} \mathbf{C}\right)$ \\
\hline 1 & $23.67 \pm 1.53$ & $6.17 \pm 0.29$ & $7.37 \pm 2.06$ & $32.70 \pm 2.11$ \\
2 & $21.67 \pm 2.88$ & $6.00 \pm 0.26$ & $6.13 \pm 2.06$ & $31.03 \pm 2.08$ \\
3 & $26.33 \pm 8.50$ & $6.10 \pm 0.10$ & $8.17 \pm 2.50$ & $30.23 \pm 2.58$ \\
\hline
\end{tabular}


Table 12. Characteristic of soil chemical

\begin{tabular}{cccc}
\hline Station & N-Total $(\boldsymbol{\%})$ & P-Total $(\boldsymbol{\%})$ & K-Total $(\boldsymbol{\%})$ \\
\hline 1 & $0.32 \pm 0.07$ & $0.08 \pm 0.00$ & $0.52 \pm 0.03$ \\
2 & $0.36 \pm 0.06$ & $0.08 \pm 0.01$ & $0.43 \pm 0.07$ \\
3 & $0.37 \pm 0.04$ & $0.09 \pm 0.01$ & $0.44 \pm 0.02$ \\
\hline
\end{tabular}

The availability of the DO parameter with a value of 0.68 is strongly correlated with macrozoobenthos diversity in mangrove waters, so it can be assumed that DO affects the presence of macrozoobenthos in mangrove waters. The highest DO value was found at station III, which was 8.17 $\mathrm{mg} / \mathrm{l}$. The higher the DO concentration in the waters, the higher its quality and vice versa, which might impact the existence of macrozoobenthos (Sahidin et al. 2018). Moreover, Harahap et al. (2018) presented that DO is positively correlated with macrozoobenthos and may indeed be employed as a bioindicator as well as a determinant of water quality.

The relationship between the number of macrozoobenthos individuals in each observation plot and environmental parameters was positive because its value was not equal to 0 . Of the four environmental parameters observed, only the DO value is significant because significant $<0.05$ with macrozoobenthos diversity, the rest have a weak type of correlation, which is depicted in Table 10. The temperature in this study owns a value of 0.33 and has a low correlation, but this value will still be tolerated and accepted by macrozoobenthos in accordance with the quality standard of the Decree of the Minister of the Environment No. 51 (2004). The temperature for marine biota is $28-32^{\circ} \mathrm{C}$, whereas the temperature at the research site ranges from $29-33^{\circ} \mathrm{C}$. Macrozoobenthos can grow optimally with $\mathrm{pH}$ values ranging from 5-9; overall from the parameters observed, it is known that these waters are still considered feasible to support macrozoobenthos survival (Basyuni et al. 2018; Susetya et al. 2018).

Station III has the highest N-Total $(0.37 \%)$ value due to its abundance of vegetation and marine life. Consequently, $\mathrm{N}$ has a major impact on plants and the availability of other nutrients. Soil nitrogen, a critical nutrient for plants, is required for plant vegetative development as well as protein synthesis (Nugroho et al. 2013). Station III has the highest Phosphorus (P-Total) value of $0.09 \%$, which is caused by the soil's acidic $\mathrm{pH}$ and the presence of organic materials from decomposition. Activity on lands, such as natural environmental impacts or human activities, can alter the availability of a soil element, one of which is phosphorus (Holliday and Gartner 2007). Potassium (KTotal) has the greatest value of $0.52 \%$ at a station I as it is the macronutrient, after nitrogen, that is most widely absorbed by plants; nevertheless, in the results gathered at the research location at a station $\mathrm{I}$, it is higher so that the nitrogen nutrients can be absorbed into the plants. Potassium is absorbed by plants in amounts equivalent to or greater than nitrogen. If the potassium in the soil is adequate for plant growth, the plant will grow well (Etesami et al. 2017).

\section{Discussion}

The vegetation analysis in the Percut Sei Tuan mangrove forest, North Sumatra, resulted in the discovery of 10 species, namely Avicennia alba, A. marina, A. officinalis, Bruguiera gymnorrhiza, Ceriops tagal, Excoecaria agallocha, Lumnitezera racemosa, $R$. apiculata, R. stylosa, and Scyphiphora hydrophllacea. The species $A$. marina was the most common one found at each growth stage, while $A$. alba was the lowest at the tree stage and $R$. stylosa in the sapling stage. At the study location study, an area bordering the sea, there are species of $A$. alba, A. marina, A. officinalis, R. apiculata, and $R$. stylosa. This finding followed Afefe et al. (2019), who reported that the characteristics of ideal mangroves that grow in areas close to the sea are often overgrown by Avicennia spp. and associated with Rhizophora spp. in sandy or mixed soil types. Recently, this finding was supported by Balke et al. (2021) as this location faces the open coast directly, i.e., faces seaward, colonizing A. marina.

The macrozoobenthos found in the Percut Sei Tuan mangrove forest, North Sumatra, consisted of two types of mollusks, Cassidula angulifera and Cassidula nucleus, two species of Gastropoda, Cerithidea obtusa and Ellobium aurisjudae, two species of Arthropoda, Evisarma versicolor and Eca tetragonon, and one species of Polychaeta, Nereis sp. The species most commonly found are from the class Gastropod, which has a high tolerance to environmental changes, as well as high adaptability and a wide distribution range. This is supported by Silaen et al. (2013) who confirmed that the density and distribution of Gastropoda depend on their environment and habitat, the presence of food, ecological pressures, and environmental changes in mangrove vegetation.

The number of individuals in the Percut Sei Tuan mangrove forest is $842.42 / \mathrm{ha}$. Based on the Decree of the Minister of the Environment No. 201 of 2004 (KepMen LH No. 201 of 2004), the standard criteria and guidelines for mangrove damage are classified as rare or the criteria for damage are $<50 \%$. While the diversity index $\left(\mathrm{H}^{\prime}\right)$ of macrozoobenthos ranged from 1.54 to $1.81 \mathrm{ind} / \mathrm{m}^{2}$, which was included in the low to a medium category, mangroves with a high density provide good shelter and support the availability of adequate nutrient intake from litter (Bayan et al. 2016). Fallen mangrove leaves will be decomposed by microbial communities that engage in further functions to produce organic matter and nutrients in the soil, land, and ecosystem (Karniati et al. 2021). This relationship maintains the ecosystem's balance in the substrate and serves as a food supply for macrozoobenthos. As per the research conducted by Nugroho et al. (2013), the higher the mangrove density, the more litter produced, which enhances the organic matter content in the substrate. The survival of marine species, particularly macrozoobenthos, will be damaged if the mangrove ecosystem is disturbed. Our findings pointed out that it is necessary to carry out rehabilitation efforts that involve the community and mangrove area management sector in a sustainable manner in the Percut Sei Tuan mangrove forest area. The impact of the destruction of the mangrove ecosystem will be very large, both from an ecological and economic perspective 
(Su et al. 2021). The marine food chain will be destroyed, leading to a decline in the fisheries sector (Macusi et al. 2021). The coastal community's protection from sea-level rise, storm surges, and tsunamis will be affected (Marois et al. 2015). Human communities living in or near mangroves will lose access to essential food, fiber, timber, chemicals, pharmaceuticals, animal feed, and fertilizers (Van Oudenhoven et al. 2015; Sari et al. 2018; Rupidara et al. 2020).

In conclusion, the current study found 10 true mangrove species where Avicennia marina was the most abundant species at each seedling, sapling, and tree level, indicating its highly relative species diversity. The physical and chemical factors of the observed parameters suggested that these mangrove waters are still considered suitable for supporting the lives of macrozoobenthos with dissolved oxygen, which was strongly correlated to macrozoobenthos diversity. Further research is required to continue exploring the diversity of macrozoobenthos on the restored mangroves.

\section{ACKNOWLEDGMENTS}

We thank the Directorate of Research and Community Service, Ministry of Education, Culture, Research, and Technology, Republic of Indonesia (No. 11/AMD/E1/ KP.PTNB/2021) through the Basic Research Scheme 2021.

\section{REFERENCES}

Afefe AA, Abbas MA, Soleman S, Khedr AH, Hatab EE. 2019. Physical and chemical characteristics of mangrove soil under marine influence. A case study on the mangrove forests at Egyptian-African Red Sea coast. Egypt J Aquat Biol Fish 23 (3): 385-399. DOI: 10.21608/ejabf.2019.47451.

Alongi DM. 2014. Carbon cycling and storage in mangrove forests. Ann Rev Mar Sci 6: 195-219. DOI: 101146/annurev-marine-010213135020.

Baderan DWK, Hamidun MS, Utina R, Rahim S, Dali R. 2019. The abundance and diversity of Mollusks in mangrove ecosystem at coastal area of North Sulawesi, Indonesia. Biodiversitas 20 (4): $987-$ 993. DOI: $10.13057 /$ biodiv/d200408.

Balke T, Vovides A, Schwarz C, Chmura GL, Ladd C, Basyuni M. 2021. Monitoring tidal hydrology in coastal wetlands with the "Mini Buoy": applications for mangrove restoration. Hydrol Earth Syst Sci 25 (3): 1229-1244. DOI: 10.5194/hess-25-1229-2021.

Balke T, Swales A, Levelock C, Herman P, Bouma T. 2015. Limits to seaward expansion of mangroves: Translating physical disturbance mechanisms into seedling survival gradients. J Exp Mar Biol Ecol 467: 16-25. DOI: 101016/jjembe201502015.

Balke T, Webb EL, van den Elzen E, Galli D, Herman PM, Bouma TJ. 2013. Seedling establishment in a dynamic sedimentary environment: A conceptual framework using mangroves. J Appl Ecol 50 (3): 740747. DOI: 101111/1365-266412067.

Barbour MG, Burk JH, Pitts WD. 1987. Terrestrial Plant Ecology. The Benjaminn/Cumming Pub Co Inc, California.

Basyuni M, Slamet B, Sulistiyono N, Munir E, Vovides A, Bunting P. 2021. Physicochemical characteristics, nutrients, and fish production in different types of mangrove forests in North Sumatra and the Aceh Provinces of Indonesia. Kuwait J Sci 48 (3): 1-14. DOI: 10.48129/kjs.v48i3.9160.

Basyuni M, Gultom K, Fitri A, Susetya IE, Wati R, Slamet B, Sulistiyono N, Yusriani E, Balke T, Bunting P. 2018. Diversity and habitat characteristics of macrozoobenthos in the mangrove forest of Lubuk
Kertang Village North Sumatra. Biodiversitas 19 (1): 311-317. DOI: 1013057/biodiv/d190142.

Bayan IE, Yulianda F, Setyobudiandi I. 2016. Degradation analysis of mangrove ecological function as macrozoobenthos habitat and its management in the Angke Kapuk Coastal Area Jakarta. Intl J Bonorowo Wetl 6 (1): 1-11. DOI: 1013057/bonorowo/w060101.

Bryan JE, Shearman PL, Asner GP, Knapp DE, Aoro G, Lokes B. 2013. Extreme differences in forest degradation in Borneo: Comparing practices in Sarawak Sabah and Brunei. Plos One 8 (7): 1-7. DOI: 101371/journalpone0069679.

Bryan-brown DN, Connolly RM, Richards DR, Adame F, Friess DA, Brown CJ. 2020. Global trends in mangrove forest fragmentation. Sci Rep 10: 7117. DOI: 101038/s41598-020-63880-1.

Chen Q, Zhao Q, Chen P, Lu H, Jian S. 2018. Eco-exergy based selforganization of the macrobenthic faunal assemblage during mangrove succession in Zhanjiang, China. Ecol Indic 95: 887-894. DOI: 10.1016/j.ecolind.2018.08.044.

Clarke KR, Warwick RM 2001. A further biodiversity index applicable to species lists: Variation in taxonomic distinctness. Mar Ecol Prog Ser 216: 265-278. DOI: 10.3354/meps216265.

Decree of the State Minister for the Environment. 2004. Number 201 of 2004: Standard Criteria and Guidelines for Determining Mangrove Damage. [Indonesia]

Eddy S, Milantara N, Sasmito SD, Kajita T, Basyuni M. 2021. Anthropogenic drivers of mangrove loss and associated carbon emissions in South Sumatra, Indonesia. Forests 12 (2): 187. DOI: 10.3390/f12020187.

Etesami H, Emami S, Alikhani HA. 2017. Potassium solubilizing bacteria (KSB): Mechanisms, promotion of plant growth, and future prospects A review. J Soil Sci Plant Nutr 17 (4): 897-911. DOI: 10.4067/S071895162017000400005.

Ghufrona RR, Kusmana C, Rusdiana O. 2015. Species composition and mangrove forest structure in Pulau Sebuku South Kalimantan. Jurnal Silvikultur Tropis 6 (1): 15-26. DOI: 1029244/j-siltrop61\%25p. [Indonesia]

Gravina MF, Cabiddu S, Como S, Floris A, Padedda BM, Pusceddu A, Magni P. 2020. Disentangling heterogeneity and commonalities in nanotidal Mediterranean lagoons through environmental features and macrozoobenthic assemblages. Estuar Coast Shelf Sci 237: 106688. DOI: $10.1016 /$ j.ecss.2020.106688.

Harahap A, Barus TA, Mulya MB, Ilyas S. 2018. Macrozoobenthos diversity as bioindicator of water quality in the Bilah river Rantauprapat. J Phys Conf Ser 1116 (1): 052026. DOI:101088/17426596/1116/5/052026.

Hidayatullah M, Eko P. 2014. Structure and composition of mangrove forest types in Golo Sepang - Boleng District West Manggarai Regency Researcher at the Kupang Forestry Research Institute $\begin{array}{lllll}\text { Wallacea. J For Res } 3 \text { (2): 151-162. DOI: } & \end{array}$ 1018330/jwallacea2014vol3iss2pp151-162.

Holliday VT, Gartner WG. 2007. Methods of soil $\mathrm{P}$ analysis in archaeology. J Archaeol Sci 34 (2): 301-333. DOI: 10.1016/j.jas.2006.05.004.

Karniati R, Sulistiyono N, Amelia R, Slamet B, Bimantara Y, Basyuni M. 2021. Mangrove ecosystem in North Sumatran (Indonesia) forests serves as a suitable habitat for mud crabs (Scylla serrata and $S$. olivacea). Biodiversitas 22 (3): 1489-1496. DOI: 1013057/biodiv/d220353.

Kasumyan AO. 2019. The taste system in fishes and the effects of environmental variables. J Fish Biol 95 (1): 155-178. DOI: 10.1111/jfb.13940.

Kitamura A, Anwar C, Chaniago A, Baba S. 2003. Mangrove Guide in Indonesia Bali and Lombok. International Society for Mangrove Ecosystem (ISME), Japan.

Li Q, Wang G, Wang H, Shrestha S, Xue B, Sun W, Yu J. 2020. Macrozoobenthos variations in shallow connected lakes under the influence of intense hydrologic pulse changes. J Hydrol 584: 124755. DOI: 101016/jjhydrol2020124755.

Macusi ED, Geronimo RC, Santos MD. 2021. Vulnerability drivers for small pelagics and milkfish aquaculture value chain determined through online participatory approach. Mar Policy 133: 104710. DOI: 10.1016/j.marpol.2021.104710.

Marois DE, Mitsch WJ. 2015. Coastal protection from tsunamis and cyclones provided by mangrove wetlands-a review. Intl J Biodivers Sci Ecosyst Serv Manag 11 (1): 71-83. DOI: 101080/215137322014997292. 
Muhammad F, Izzati M, Mukid MA. 2017. Macrobenthos as an indicator of the fertility level of ponds on the north coast of Central Java Biomes. Biol Sci Periodic 19 (1): 38-46. DOI: 1014710/bioma1913846

Murdiyarso D, Purbopuspito J, Kauffman JB, Warren MW, Sasmito SD, Donato DC, Manuri S, Krisnawati H, Taberima S, Kurnianto S. 2015. The potential of Indonesian mangrove forests for global climate change mitigation. Nat Clim Chang 5 (12): 1089-1092. DOI: 101038/Nclimate2734

Ningsih SS, Widhiastuti R, Utomo B, Guslim. 2011. Inventory of mangrove forest as part of management effort in coastal area of Deli Serdang North Sumatra. Intl J Bonorowo Wetl 1: 58-69. DOI 10.13057/bonorowo/w010202.

Nugroho RA, Widada S, Pribadi R. 2013. Study of organic matter and mineral content (N P K Fe and $\mathrm{Mg}$ ) of sediment in mangrove area Bedono Village Sayung District Demak Regency. J Mar Res 2 (1): 62-70. DOI: 1014710/jmrv2i12057.

Obolewski K. 2011. Macrozoobenthos patterns along environmental gradients and hydrological connectivity of oxbow lakes. Ecol Eng 37 (5): 796-805. DOI: 101016/jecoleng201006037.

Odum EP. 1993. Fundamentals of Ecology. Gadjah Mada University Press, Yogyakarta. [Indonesian]

Parmadi EH, Irma D, Sofyatuddin K. 2016. Importance value index of mangrove vegetation in Kuala Idi Area, East Aceh Regency. Sci J Mar Fish Stud Unsyiah 1 (1): 82-95. [Indonesian]

Pearson T, Walker S, Brown S. 2005. Sourcebook for Land Use Land-use Change and Forestry Projects Winrock International and the BioKarbon Fund of the World Bank 57. World Bank, Washington DC.

Poedjirahajoe E, Marsono D, Wardhani FK. 2017. The use of principal component analysis in the spatial distribution of mangrove vegetation on the North Coast of Pemalang. J For Sci 11 (1): 29-42. DOI: 10.22146/jik.24885. [Indonesian]

Rupidara AD, Tisera WL, Ledo ME. 2020. Study of mangrove etnobotany in Kupang. J Trop Mar Sci Technol 12 (3): 875-884. DOI 1029244/jitktv12i333243.

Noor R, Khazali YM, Suryadiputra INN. 2006. Guide to Introduction to Mangroves in Indonesia. PHKA/WI-IP, Bogor. [Indonesia]

Sahidin A, Zahidah Z, Herawati H, Wardiatno Y, Setyobudiandi I, Partasasmita R. 2018. Macrozoobenthos as bioindicator of ecological status in Tanjung Pasir Coastal, Tangerang District, Banten Province, Indonesia. Biodiversitas 19 (3): 1123-1129. DOI: 10.13057/biodiv/d190347.

Samidurai K, Saravanakumar A, Kathiresan K. 2012. Spatial and temporal distribution of macrobenthos in different mangrove ecosystems of Tamil Nadu Coast, India. Environ Monit Assess 184 (7): 4079-4096. DOI: $10.1007 / \mathrm{s} 10661-011-2245-\mathrm{x}$.
Sari DP, Basyuni M, Hasibuan PA, Sumardi S, Nuryawan A, Wati R 2018. Cytotoxic and antiproliferative activity of polyisoprenoids in seventeen mangroves species against WiDr colon cancer cells. Asian Pac J Cancer Prev 19 (12): 3393-3400. DOI: 1031557/APJCP201819123393.

Sasmito SD, Taillardat P, Clendenning JN, Cameron C, Friess DA, Murdiyarso D, Hutley LB. 2019. Effect of land-use and land-cover change on mangrove blue carbon: A systematic review. Glob Change Biol 25 (12): 4291-4302. DOI: 101111/gcb14774.

Silaen IF, Hendrarto B, Nitisupardjo M. 2013. Distribution and abundance of gastropods in the mangrove forest of Teluk Awur Jepara. MAQUARES: Manag Aquat Resour J 2 (3): 93-103. [Indonesian]

Simamora HP, Khairijon K, Isda MN. 2014. Analysis of mangrove vegetation in the mangrove ecosystem of Tapian Nauli I Village, Tapian Nauli District, Central Tapanuli Regency, North Sumatra Province. JOM MIPA, Riau University 1 (2): 1-10. [Indonesian]

Singh JK. 2020. Structural characteristics of mangrove forest in different coastal habitats of Gulf of Khambhat arid region of Gujarat, west coast of India. Heliyon 6 (8): e04685. DOI: 10.1016/j.heliyon.2020.e04685.

Sreelekshmi S, Nandan SB, Kaimal SV, Radhakrishnan CK, Suresh VR. 2020. Mangrove species diversity, stand structure and zonation pattern in relation to environmental factors, A case study at Sundarban delta, East Coast of India. Reg Stud Mar Sci 35: 101111. DOI: 10.1016/j.rsma.2020.101111.

Su J, Friess DA, Gasparatos A. 2021. A meta-analysis of the ecological and economic outcomes of mangrove restoration. Nat Commun 12 (1): 1-13. DOI: $10.1038 / \mathrm{s} 41467-021-25349-1$.

Susetya IE, Basyuni M, Desrita D, Susilowati A, Kajita T. 2021. Density and characteristics of Green mussels (Perna viridis) in Percut Sei Tuan coastal North Sumatra Indonesia. Biodiversitas 22 (2): 10431050. DOI: 1013057/biodiv/d220261.

Susetya IE, Desrita D, Ginting EDD, Fauzan M, Yusni E, Saridu SA. 2018. Diversity of bivalves in Tanjung Balai Asahan Waters North Sumatra Indonesia. Biodiversitas 19 (3): 1147-1153. DOI: 1013057/biodiv/d190350.

Tapilatu Y, Pelasula D. 2012. Fouling organisms associated with mangrove in Ambon inner bay. J Mar Sci Technol Trop 4 (2): 267279. DOI: $1029244 /$ jitktv4i27789.

Theuerkauff D, Rivera-ingraham GA, Roques JAC, Azzopardi L, Bertini M, Lejeune M, Farcy E, Lignot JH, Sucré E. 2018. Salinity variation in a mangrove ecosystem: A physiological investigation to assess potential consequences of salinity disturbances on mangrove crabs. Zool Stud 57: e36. DOI: 10.6620/ZS.2018.57-36.

van Oudenhoven AP, Siahainenia AJ, Sualia I, Tonneijck FH, van der Ploeg S, de Groot RS, Leemans R. 2015. Effects of different management regimes on mangrove ecosystem services in Java, Indonesia. Ocean Coast Manag 116: 353-367. DOI: 10.1016/j. 